\title{
PECULIARITES OF INTERACTION BETWEEN 3-(2-AMINOPHENYL)-6-R-1,2,4-TRIAZIN-5(2H)-ONES AND CYCLIC ANHYDRIDES OF NON-SYMMETRIC DICARBOXYLIC ACIDS
}

\author{
O.Yu.Voskoboynik ${ }^{1}$, D.Yu.Skorina ${ }^{1}$, S.V.Shishkina ${ }^{2}$, O.V.Shishkin ${ }^{2}$, \\ S.I.Kovalenko' ${ }^{1}$, V.V.Ivchuk ${ }^{3}$
}

${ }^{1}$ Zaporizhia State Medical University, Zaporizhia

26, Mayakovsky ave., 69035, Zaporizhia, Ukraine. E-mail: kovalenkosergiy@gmail.com

${ }^{2}$ State Scientific Institution "Institute for Single Crystals" of the National Academy of Sciences of Ukraine

${ }^{3}$ Kryvui Rih Institute of Metallurgy of Kryvui Rih National University

Key words: anhydrides of non-symmetric dicarboxylic acids; cyclisation; X-ray experiment

The peculiarities of the reaction between 3-(2-aminophenyl)-6-R-1,2,4-triazin-5(2H)-ones and cyclic anhydrides of non-symmetric (2-methylsuccinic, 2-phenylsuccinic and camphoric) acids have been described in the present article. The influence of electronic and steric effects of substituents in the anhydride molecule on cyclisation processes has been discussed. The results have shown that the interaction of 3-(2-aminophenyl)-6-R-1,2,4-triazin$5(2 \mathrm{H})$-ones mentioned above with 2-methylsuccinic and 2-phenylsuccinic acid anhydrides proceeded non-selectively and yielded the mixtures of 2- $\mathrm{R}_{1}-3-(2-0 x \mathrm{-}-3-\mathrm{R}-2 \mathrm{H}-[1,2,4]$ triazino[2,3-c]quinazoline-6-yl)propanoic acids and 1-(2-(5-oxo-6-R-2,5-dihydro-1,2,4-triazin-3-yl)phenyl)-3-R,-pyrrolidine-2,5-diones. It has been found that low regioselectivity of the acylation process may be explained by insignificant electronic effects of substituents (of the methyl and phenyl fragment) in position 2 of the anhydride molecule on the electrophilic reaction centre. It has been also determined that the reaction between 3-(2-aminophenyl)-6- $R$-1,2,4-triazin-5(2H)-ones and camphoric anhydride proceeds regioselectively and yielded 1,2,2-trimethyl-3-(3-R-2-oxo-2H-[1,2,4]triazino[2,3-c]quinazolin6-yl)cyclopentan-1-carboxylic acids. Regioselectivity of the interaction mentioned above may be explained by the steric effect of the methyl group. Identity of compounds has been proven by LC-MS, the structure has been determined via a set of characteristic signals in ${ }^{1} \mathrm{H} N M R,{ }^{13} \mathrm{C} N M R$ spectra and position of cross peaks in the correlation HSQC-experiment. Mass spectra of the compounds synthesized have been also studied, the principal directions of the molecule fragmentation have been described. The structure of 1,2,2-trimethyl-3-(3-methyl2-oxo-2H-[1,2,4]triazino[2,3-c]quinazolin-6-yl)cyclopentane-1-carboxylic acid has been proven by X-ray analysis.

ОСОБЛИВОСТІ ВЗАЄМОДIї 3-(2-АМІНОФЕНІЛ)-6-R-1,2,4-ТРИАЗИН-5(2H)-ОНІВ ТА ЦИКЛІЧНИХ АНГІДРИДІВ НЕСИМЕТРИЧНИХ ДИКАРБОНОВИХ КИСЛОТ

О.Ю.Воскобойнік, Д.Ю.Скорина, С.В.Шишкіна, О.В.Шишкін, С.І.Коваленко, В.В.Івчук

Ключові слова: ангідриди несиметричних дикарбонових кислот; циклізація; рентгеноструктурне дослідження

Описані особливості реакції між 3-(2-амінофеніл)-6-R-1,2,4-триазин-5(2H)-онами з ангідридами несиметричних дикарбонових кислот (2-метилбурштинової, 2-френілбурштинової та камфрорної) кислот. Обговорено вплив електронних та стеричних ефектів замісника у молекулі ангідриду на процеси циклізаuіiі. Результати показали, що взаємодія наведених вище 3-(2-амінофреніл)-6-R-1,2,4-триазин-5(2H)-онів з ангідридами 2-метилбурштинової та 2-френілбурштинової кислот перебігала нерегіоселективно 3 утворенням суміші 2-R -3-(2-оксо-3-R-2H-[1,2,4]триазино[2,3-c]хіназолін-6-іл)пропанових кислот та 1-(2(5-оксо-6-R-2,5-дигідро-1,2,4mриазин-3-іл)френіл)-3- $R_{1}$-піролідин-2,5-діонів. Показано, що низька регіоселективність процесу ацилювання може бути пояснена незначними електронними ефектами замісників (метального та фенільного фррагменту) у положенні 2 молекули ангідриду на електрофрільний реакційний центр. Також встановлено, що реакція між 3-(2-амінофреніл)-6-R-1,2,4-триазин-5(2H)-онами та ангідридом каморорної кислоти перебігає регіоселективно та приводить до утворення 1,2,2-триметил-3-(3R-2-оксо-2H-[1, 2, 4]триазино[2,3-с]хіназолін-6-іл)циклопентан-1-карбонових кислот. Селективність зазначеної вище реакції може бути пояснена стеричними ефректами метальної групи. Індивідуальність сполук підтверджена методом LC-MS, структуру встановлено за положенням характеристичних сигналів ${ }^{1} \mathrm{H}$ ЯMP ma ${ }^{13} \mathrm{C}$ ЯMP-спектрах та за положенням крос-піків у кореляційному HSQC-експерименті. Також були досліджені мас-спектри синтезованих сполук та описані основні напрямки фрагментації молекулярних іонів. Структуру 1,2,2-триметил-3-(3-метил-2-оксо-2H-[1,2,4]триазино[2,3-с]хіназолін-6-іл) циклопентан-1-карбонової кислоти було доведено за допомогою рентгеноструктурного дослідження.

ОСОБЕННОСТИ ВЗАИМОДЕЙСТВИЯ 3-(2-АМИНОФЕНИЛ)-6-R-1,2,4-ТРИАЗИН-5(2Н)-ОНОВ И ЦИКЛИЧЕСКИХ АНГИДРИДОВ НЕСИММЕТРИЧЕСКИХ ДИКАРБОНОВЫХ КИСЛОТ

А.Ю.Воскобойник, Д.Ю.Скорина, С.В.Шишкина, О.В.Шишкин, С.И.Коваленко, В.В.Ивчук

Ключевые слова: ангидриды несимметрических дикарбоновых кислот; циклизация; рентгеноструктурные исследования

Описаны особенности реакции между 3-(2-аминофенил)-6-R-1,2,4-триазин-5(2H)-онами и ангидридами несимметричных дикарбоновых кислот (2-метилянтарной, 2-френилянтарной и камфорной) кислот. 
Проведено обсуждение влияния электронных и стерических эфрфектов заместителей на процессы циклизации. Результаты показали, что взаимодействие приведенных выше 3-(2-аминофенил)-6-R-1,2,4триазин-5(2Н)-онов с ангидридами 2-метилянтарной и 2-френилянтарной кислот протекало не ре-

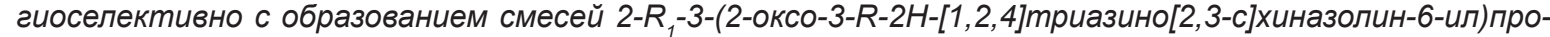
пановых кислот и 1-(2-(5-оксо-6-R-2,5-дигидро-1,2,4триазин-3-ил)френил)-3- $R_{1}$-пиролидин-2,5-дионов. Показано, что низкая региоселективность процесса ацилирования может быть объяснена незначительными электронными эфрфектами заместителей (метильного и фенильного фррагмента) в положении 2 молекулы ангидрида на электрофильный реакционный центр. Также установлено, что реакция между 3-(2-аминофенил)-6-R-1,2,4-триазин-5(2H)-онами и ангидридом камфорной кислоты протекает региоселективно и приводит к образованию 1,2,2-триметил-3-(3-R-2-оксо-2H-[1,2,4]триазино[2,3-с]хиназолин6-ил)циклопентан-1-карбоновых кислот. Селективность реакции в данном случае может быть объяснена стерическим эфрфректом метильной группы. Индивидуальность соединений подтверждена методами LC-MS, структуру установлено по положению характеристических сигналов в ${ }^{1} \mathrm{H}$ ЯMP ${ }^{13} \mathrm{C}$ ЯМР-спектрах и по положению кросс-пиков в корреляционном HSQC-эксперименте. Также были исследованы масс-спектры синтезированных соединений и описаны основные направления фррагментации молекулярных ионов. Структуру 1,2,2-триметил-3-(3-метил-2-оксо-2Н-[1,2,4]триазино[2,3-с]хиназолин6-ил)циклопентан-1-карбоновой кислоты было доказано с помощью рентгеноструктурного анализа.

To study chemical transformations of heterocyclic systems is a quite relevant problem in view of its importance in elaboration of new approaches for synthesis of novel compounds aimed at searching the potent bioactive agents. Studies devoted to creation of "scaffolds" - compounds, which may be used as the basis for synthesis of numerous combinatorial libraries, are of special practical importance. In our previous work [1] we dealt with substituted 3-(2-aminophenyl)-6-R-1,2,4-triazin-5(2H)-ones as 1,5-NCCCN binucleophilic compounds, which may be used as precursors for synthesis of various derivatives of 3-R$2 H$ - $[1,2,4]$ triazino[2,3-c]quinazoline-2-ones with expressed biological activities $[2,3,4,5]$. In our another publication we described the interaction of (2-aminophenyl)-6-R-1,2,4-triazin-5(2H)-ones with succinic and glutaric anhydride; it led to formation of the corresponding 3-(3-R-2-oxo- $2 \mathrm{H}$-[1,2,4] triazino[2,3-c]quinazolin-6-yl)alkylcarboxilyc acids [6].

The study of the biological action of the compounds mentioned above and their salts has shown that they reveal a high actoprotective and cerebroprotective activities, and may be characterized as promising objects of research aimed at creating new medicines. Taking into consideration the abovementioned fact we decided to extend the potential of the reaction between 3-(2-aminophenyl)-6-R-1,2,4-triazin$5(2 \mathrm{H})$-ones and cyclic anhydrides of dicarboxilic acids as the method for preparation of carboxyl-con- taining derivatives of $[1,2,4]$ triazino[2,3-c]quinazoline as possible bioactive compounds. Anhydrides of 2-methylsuccinic, 2-phenylsuccinic and camphoric acids have been used as the research objects. It is important to mention that structural features of the last described, in particular electronic and steric effects of substituents, may cause the ambiguous course of the reaction.

\section{Results and Discussion}

As initial compounds we used 1.1-1.6, reactions were carried out in conditions similar to the described earlier [6], namely by boiling of the starting substances in acetic acid for 6 hours. The results obtained were quite unexpected, so, according to LC-MS data the interaction between 3-(2-aminophenyl)-6-R-1,2, 4-triazin-5(2H)-ones 1.1-1.6 and 2-methylsuccinic anhydride occurred ambiguously and led to the formation of the mixture of 2-methyl-3-(2-oxo-3-R-2H$[1,2,4]$ triazino [2,3-c] quinazoline-6-yl)propanoic acid as a major product and 3-methyl-1-(2-(6-R-5-oxo2,5-dihydro-1,2,4-triazino-3-yl)phenyl)pyrrolidin-2,5diones (3.1-3.6) as the minor one (Scheme 1). A low regioselectivity of the acylation process may be explained by - an insignificant inductive effect of the methyl group on the electrophilic reaction centre. Target compounds 2.1-2.6 were isolated by crystallization from methanol, and to confirm the structure of compound 3.1 it was isolated from the reaction mixture.

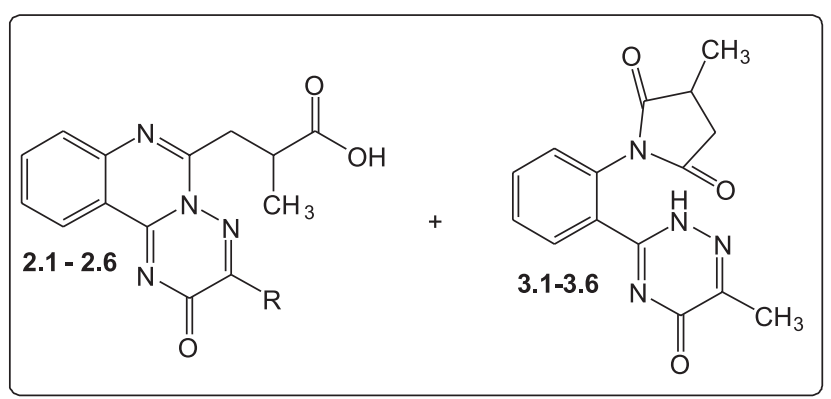



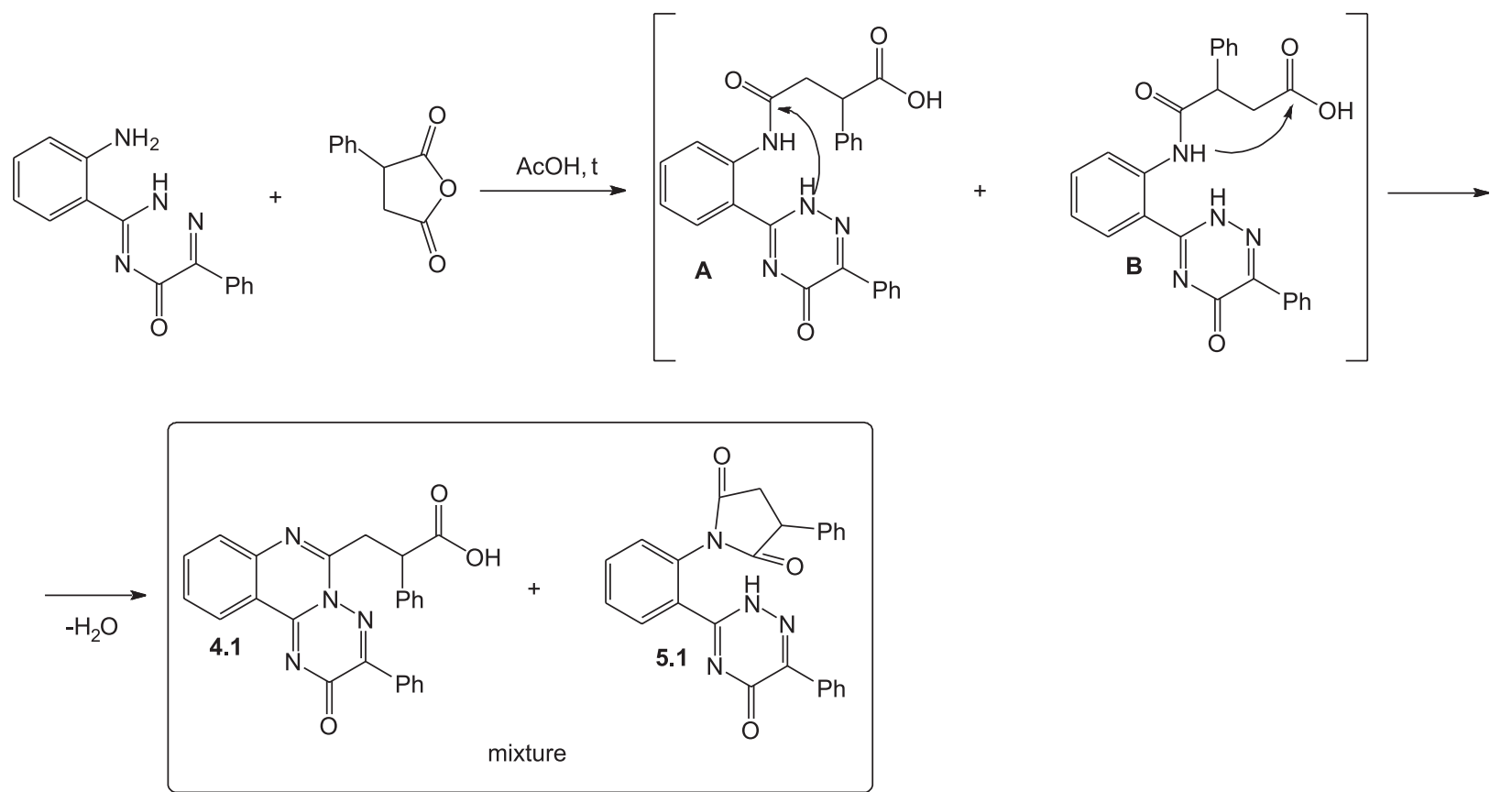

Scheme 2. Interaction of 3-(2-aminophenyl)-6-R-1,2,4-triazin-5(2H)-ones with 2-phenylsuccinic anhydride.

Identity of compounds $\mathbf{2 . 1 - 2 . 6}$ was proven by LC-MS, the structure was determined via a set of characteristic signals in ${ }^{1} \mathrm{H} N M R,{ }^{13} \mathrm{C}$ NMR spectra and position of cross peaks in the correlation HSQC-experiment. In ${ }^{1} \mathrm{H}$ NMR-spectra of the compounds mentioned the signals of the carboxylic group proton at $12.10-12.36 \mathrm{ppm}$ are characteristic. Location of the ABCD-system of the benzene fragment of the quinazoline system in a comparatively low field additionally confirms formation of the electron deficient tricyclic system. Mutual location of signals of the carboxyalkyl fragment, in particular signals of stereotopic protons of the methylene fragment in the aliphatic part at 3.74-3.79 and 3.10-3.40 ppm, allows to suggest that the methyl group is located at $\alpha$-position relative to the carboxylic group. Location of other signals in ${ }^{1} \mathrm{H}$ NMR and ${ }^{13} \mathrm{C}$ NMR-spectra, as well as location of cross peaks in correlation of the HSQC-experiment also confirm the structures proposed.

${ }^{1} \mathrm{H}$ NMR-spectra of compounds $\mathbf{3 . 1}$ substantially differ from the spectra of compounds 2.1-2.6. Thus, in the spectra of compound $\mathbf{3 . 1}$ instead of the carboxylic group signal the abnormally deshielded NHproton signal at $13.19 \mathrm{ppm}$ was detected. The protons of the benzene cycle of the quinazoline fragment were located in quite higher field comparing to the spectra of compounds 2.1-2.6 indicating the absence of the electron deficient triazinoquinazoline system.

The unexpected results were also obtained while studying the interaction of 3-(2-aminophenyl)-6-phenyl-1,2,4-triazine-5(2H)-ones with 2-phenylsuccinic anhydride. According to LC-MS data boiling of the compounds mentioned above in acetic acid yielded the mixture of two compounds with the equivalent value of $\mathrm{m} / \mathrm{z}$ corresponding to the molecular weight of proper 3-(2-oxo-3-phenyl-2H-[1,2,4] triazino[2,3-c] quinazolin-6-yl)-2-phenyl-propanoic acid and 1-(2(5-oxo-6-phenyl-2,5-dihydro-1,2,4-triazino-3-yl)phenyl)-3-phenylpyrrolidine-2,5-dione.

Formation of the products mentioned, as we consider, may be explained by the fact that the electronic effect of the phenyl moiety cannot be characterized as an obvious donor or acceptor. Thus, reactivity of carbonyl groups is approximately equal, which, in turn, causes nonselective acylation of the amino group. Intermediates $\mathbf{A}$ and $\mathbf{B}$ formed undergo further dehydration. Dehydration of intermediate $\mathbf{A}$ leads to formation of the triazinoquinazoline system, at the same time such direction of dehydration is impossible for intermediate $\mathbf{B}$ in consequence of steric restrictions. In this case, there was the alternative direction of cyclisation followed by formation of the corresponding 1-(2-(5-oxo-6-phenyl-2,5-dihydro-1,2,4-triazin-3yl)phenyl)-3-phenylpyrrolidin-2,5-dione.

3-(2-Oxo-3-phenyl-2H-[1,2,4] triazino[2,3-c] quinazoline-6-yl)-2-phenylpropanoic acid (4.1) was isolated from the mixture of the products and characterized as an individual compound. The ${ }^{1} \mathrm{H}$ NMR spectral pattern of the compound mentioned was similar to the spectra of compounds $\mathbf{2 . 1 - 2 . 5}$. Thus, signals of the carboxylic group at $12.59 \mathrm{ppm}$, the ABCD system of triazinoquinazoline protons and the carboxyalkyl fragment were present in ${ }^{1} \mathrm{H}$ NMR-spectra of 4.1. The signals being characteristic for the phenyl moiety in position 3 were also observed.

The interaction of 3-(2-aminophenyl)-6-R-1,2,4triazin-5(2H)-ones with camphoric anhydride was also studied. The reaction given above was especially interesting considering that among products of condensation of camphoric anhydride with diamines the 


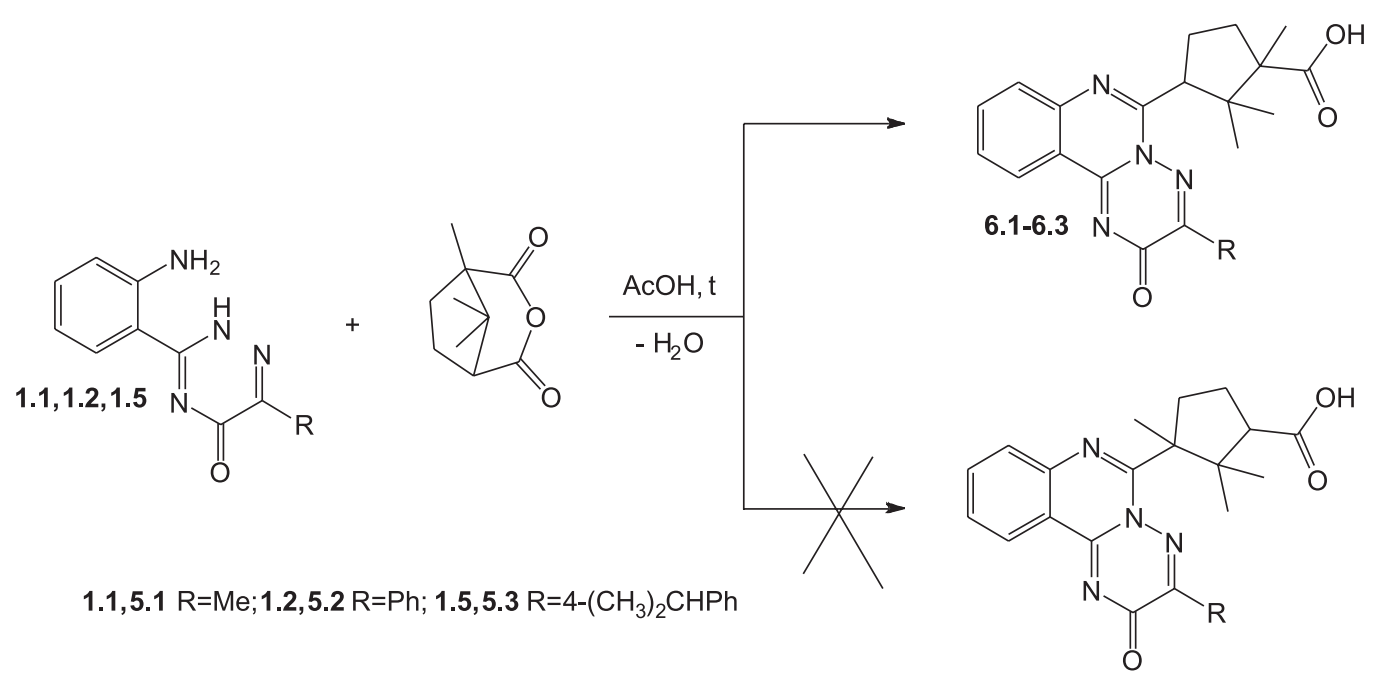

Scheme 3. Interaction 3-(2-aminophenyl)-6-R-1,2,4-triazin-5(2H)-ones with camphoric anhydride.

potent hypoglycemic agents were found [9]. According to the data of physicochemical methods the interaction of the compound mentioned occurred regioselectively and yielded 1,2,2-trimethyl-3-(3-R-2-oxo$2 \mathrm{H}-[1,2,4]$ triazino[2,3-c] quinazolin-6-yl)cyclopentan1 -carboxylic acids.

To confirm the structure of compounds 6.1-6.3 the complex of physicochemical methods such as LC-MS, ${ }^{1} \mathrm{H}$ NMR-, ${ }^{13} \mathrm{C}$ NMR- and mass-spectrometry was used. The molecular weight of compounds, signals of the carboxylic group (11.91-11.97 ppm) and protons of the quinazoline fragment in ${ }^{1} \mathrm{H}$ NMR spectra and ${ }^{13} \mathrm{C}$ NMR spectral pattern indicated formation of the triazinoquinazoline system, but we could not differentiate the product out of two alternative structures. The mass spectral (EI) pattern of compound $\mathbf{6 . 1}$ was characterized by the complex structure, but also did not allow definitely evaluating direction of the reaction. Primary fragmentation was caused by the decar-

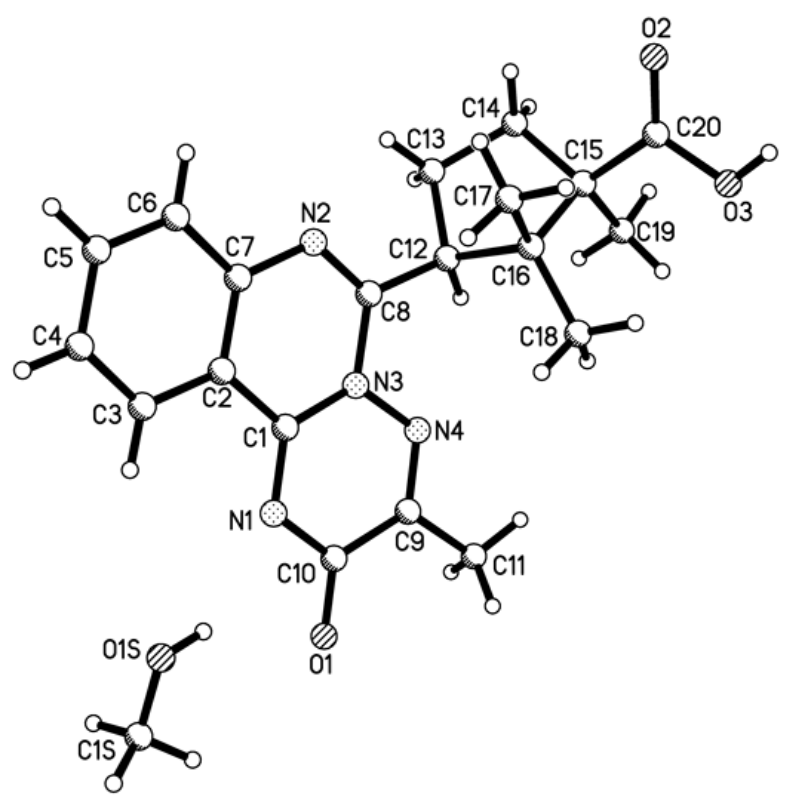

Fig. 1. The molecular structure of compound 6.1 according to X-ray diffraction data. boxylation process (the signal with $\mathrm{m} / \mathrm{z}=321, \mathrm{I}_{\text {rel }}=$ $\left.29.0 \%\left(\mathrm{~F}_{2}\right)\right)$ and degradation of triazine fragments on bonds C2-C3 and N4-N5 (signals with $\mathrm{m} / \mathrm{z}=325$, $\left.\mathrm{I}_{\text {rel }}=16.8 \%\left(\mathrm{~F}_{2}\right)\right)$. The subsequent elimination of $\mathrm{CO}$ from the fragment ion $\mathrm{F}_{2}$ yielded the fragmental ion $\mathrm{F}_{3}$ (the signal with $\mathrm{m} / \mathrm{z}=297, \mathrm{I}_{\text {rel }}=30.4 \%$ ). Degradation of the cyclopentane moiety of fragments $\mathrm{F}_{1}$ and $\mathrm{F}_{2}$ caused the presence of signal series, including the most intensive with $\mathrm{m} / \mathrm{z}=198$. Elimination of the cycloalkyl fragment from $\mathrm{F}_{2}$ yielded an ion with $\mathrm{m} / \mathrm{z}=$ 171 and the intensity of $28.4 \%$ being typical for the triazinoquinazoline system and fragmentation was undergone according to the directions described [10]. Considering that the complex of spectral methods did not allow to identify the structure of the products formed the X-ray structural study was used; it showed that we obtained 1,2,2-trimethyl-3-(3-R-2-oxo-2H$[1,2,4]$ triazino[2,3-c]quinazoln-6-yl)cyclopentan-1-carboxylic acids.

The tricyclic fragment of molecule $\mathbf{6 . 1}$ is planar within $0.03 \AA$. The saturated five-membered substituent adopts an envelope conformation where deviation of the $\mathrm{C} 16$ atom from the mean plane of the remaining atoms of the ring is $-0.65 \AA$. The five-membered ring is turned in such way that its planar part is slightly non-coplanar to the N2-C8 endocyclic double bond (the N2-C8-C12-C13 torsion angle is $32.5(3)^{\circ}$ ). It can be assumed that C12-H...N4 (H...N 2.31 A C-H...N $104^{\circ}$ ) and C13-H13b...N2 (H...N $2.43 \AA \AA$ C-H...N 107 $\left.{ }^{\circ}\right)$ weak intramolecular hydrogen bonds promote such location of the saturated ring. The methyl group at the $\mathrm{C} 15$ atom is located in the axial position (the C13-C14-C15-C19 torsion angle is $91.3(3)^{\circ}$ ) and the carboxyl group has equatorial orientation and is almost coplanar to the C14-C15 endocyclic bond (the C13-C14-C15-C20 and C14-C15-C20-O2 torsion angles are $147.8(2)^{\circ}$ and $-12.1(3)^{\circ}$, respectively). The presence of the geminal substituents at the neighbouring atoms of the pentane ring leads to the appearance of the significant steric repulsion (the shor- 
tened intramolecular contacts: H12...H19c $2.27 \AA$ (the van der Waals radii sum [11] is $2.34 \AA$ ), H12...C19 $2.84 \AA$ (2.87 ̊̊), H17a...C8 $2.60 \AA$ ( (2.87 ̊), H17b...C13 $2.75 \AA ̊(2.87 \AA)$, H17b...C14 2.66 $(2.87 \AA$ ), H17c...C20 $2.55 \AA$ ( $2.87 \AA), \mathrm{H} 18 \mathrm{c} . . . \mathrm{C} 192.63 \AA$ (2.87 $\mathrm{A}), \mathrm{H} 18 \mathrm{c} . . . \mathrm{H} 19 \mathrm{a}$ $2.22 \AA$ (2.34 $),$ H19a...C18 $2.66 \AA$ (2.87 $)$ ), H19c...C12 $2.77 \AA$ ( $2.87 \AA)$ ), it causes elongation of the C12-C16 bond up to $1.567(3) \AA$ as compared with its mean value [12] $1.556 \AA$.

In the crystal phase molecules $\mathbf{6 . 1}$ form the zigzag chains along the $\left[\begin{array}{lll}0 & 1 & 0\end{array}\right]$ crystallographic direction due to formation of the $03-\mathrm{H} . . .01^{\prime}(1.5-\mathrm{x},-0.5+\mathrm{y}$, $0.5-\mathrm{z}$ ) intermolecular hydrogen bond (H...O $1.93 \AA$, $\mathrm{O}-\mathrm{H} . . . \mathrm{O} 164^{\circ}$ ), it promotes the elongation of the $\mathrm{C} 10-01$ bond up to $1.233(3) \AA$ (the mean value is $1.210 \AA$ ). The methanol solvate and $\mathbf{6 . 1}$ molecules are bonded by the $01 \mathrm{~s}-\mathrm{H} \ldots \mathrm{N} 1$ intermolecular hydrogen bond $(\mathrm{H} \ldots \mathrm{N}$ $2.32 \AA ̊$ O $-\mathrm{H} . . . \mathrm{N} 156^{\circ}$ ).

\section{Experimental Part}

Melting points were determined in open capillary tubes and were uncorrected. The elemental analyses $(\mathrm{C}, \mathrm{H}, \mathrm{N}, \mathrm{S})$ were performed using an ELEMENTAR vario EL Cube analyzer (USA). Analyses were indicated by the symbols of the elements or functions within $\pm 0.3 \%$ of the theoretical values. IR spectra (4000$600 \mathrm{~cm}^{-1}$ ) were recorded on a Bruker ALPHA FT-IR spectrometer (Bruker Bioscience, Germany) using a module for measuring attenuated total reflection (ATR). ${ }^{1} \mathrm{H}$ NMR spectra (400 MHz) and ${ }^{13} \mathrm{C}$ NMR spectra $(100 \mathrm{MHz})$ : were recorded on Varian-Mercury 400 (Varian Inc., Palo Alto, CA, USA) spectrometers with TMS as an internal standard in DMSO-d6 solution. LC-MS were recorded using the chromatography/mass spectrometric system consisting of a "Agilent 1100 Series" high performance liquid chromatograph (Agilent, Palo Alto, CA, USA) equipped with a diode-matrix and a "Agilent LC/MSD SL" mass-selective detector (atmospheric pressure chemical ionization - APCI). Electron impact mass spectra (EI-MS) were recorded on a Varian $1200 \mathrm{~L}$ instrument at $70 \mathrm{eV}$ (Varian, USA). The purity of all the compounds obtained was checked by $1 \mathrm{H}-\mathrm{NMR}$ and LC-MS.

Compounds 1.1-1.6 were obtained according to the synthetic protocols described [1].

The general method for preparation of 2-methyl-3-(2-oxo-3-aryl-2H-[1,2,4]triazino [2,3-c] quinazolin-6-yl)propanoic acids.

To the suspension of $0.003 \mathrm{M}$ of the corresponding 3-(2-aminophenyl)-6-aryl-1,2,4-triazin-5(2H)-one

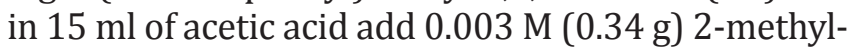
succinic anhydride, reflux the mixture for 6 hours and cool. Evaporate the solvent under low pressure, crystallize the residue from methanol.

2-Methyl-3-(2-oxo-3-phenyl-2H-[1,2,4]triazino [2,3-c]quinazolin-6-yl)propanoic acid (2.1). Yield 52.32\%. M.p. $-210-212^{\circ} \mathrm{C} ;{ }^{1} \mathrm{H}$ NMR (400 MHz, DMSO-d6) $\delta 12.36$ (s, 1H,COOH), 8.57 (d, J = $8.0 \mathrm{~Hz}, 1 \mathrm{H}, \mathrm{H}-8$ ), $8.01(\mathrm{t}, \mathrm{J}=7.6 \mathrm{~Hz}, 1 \mathrm{H}, \mathrm{H}-9), 7.84(\mathrm{~d}, \mathrm{~J}=8.1 \mathrm{~Hz}, 1 \mathrm{H}$, $\mathrm{H}-8), 7.77$ (t, J = 7.6 Hz, 1H, H-10), 3.70 (dd, J = 16.1, $\left.6.8 \mathrm{~Hz}, 1 \mathrm{H},-\mathrm{CH}_{2} \mathrm{CH}\left(\mathrm{CH}_{3}\right) \mathrm{COOH}\right), 3.30-3.10(\mathrm{~m}, \mathrm{~J}=19.8$, $\left.6.6 \mathrm{~Hz}, 2 \mathrm{H},-\mathrm{CH}_{2} \mathrm{CH}\left(\mathrm{CH}_{3}\right) \mathrm{COOH}\right), 2.21\left(\mathrm{~s}, 1 \mathrm{H}, \mathrm{CH}_{3}\right), 1.30$ $\left(\mathrm{d}, \mathrm{J}=6.7 \mathrm{~Hz}, 3 \mathrm{H},-\mathrm{CH}_{2} \mathrm{CH}\left(\mathrm{CH}_{3}\right) \mathrm{COOH}\right) ; \mathrm{LC}-\mathrm{MS}, \mathrm{m} / \mathrm{z}$ $=299[\mathrm{M}+1]$; Calculated for: $\mathrm{C}_{15} \mathrm{H}_{14} \mathrm{~N}_{4} \mathrm{O}_{3}: \mathrm{C}, 60.40 ; \mathrm{H}$, 4.73; N, 18.78; Found: C, 60.44; H, 4.78; N, 18.81.

2-Methyl-3-(2-oxo-3-phenyl-2H-[1,2,4]triazino [2,3-c]quinazoline-6-yl)propanoic acid (2.2). Yield 46.32\%. M.p. -226-228 ${ }^{\circ} \mathrm{C} ;{ }^{1}$ H NMR (400 MHz, DMSO-d6) $\delta 12.36(\mathrm{~s}, 1 \mathrm{H}, \mathrm{COOH}), 8.57$ (d, J = $8.0 \mathrm{~Hz}, 1 \mathrm{H}, \mathrm{H}-8)$, 8.28 (d, J = 7.1 Hz, 2H, 3-Ph H-2, 6), 8.01 (t, J = 7.6 Hz, $1 \mathrm{H}, \mathrm{H}-9), 7.84(\mathrm{~d}, \mathrm{~J}=8.1 \mathrm{~Hz}, 1 \mathrm{H}, \mathrm{H}-8), 7.77(\mathrm{t}, \mathrm{J}=7.6 \mathrm{~Hz}$, 1H, H-10), 7.68-7.45 (m, 3H, 3-Ph H-3,4,5), 3.70 (dd,J $\left.=16.1,6.8 \mathrm{~Hz}, 1 \mathrm{H},-\mathrm{CH}_{2} \mathrm{CH}\left(\mathrm{CH}_{3}\right) \mathrm{COOH}\right), 3.30-3.10(\mathrm{~m}$, $\left.\mathrm{J}=19.8,6.6 \mathrm{~Hz}, 2 \mathrm{H},-\mathrm{CH}_{2} \mathrm{CH}\left(\mathrm{CH}_{3}\right) \mathrm{COOH}\right), 1.30(\mathrm{~d}, \mathrm{~J}=$ $\left.6.7 \mathrm{~Hz}, 3 \mathrm{H},-\mathrm{CH}_{2} \mathrm{CH}\left(\mathrm{CH}_{3}\right) \mathrm{COOH}\right) ;{ }^{13} \mathrm{C}$ NMR $(101 \mathrm{MHz}$, DMSO) $\delta 159.46,158.23,158.02,152.52,151.00,149.38$, $143.24,135.40,132.12,131.29,129.35,128.52,128.38$, $127.37,125.47,119.24,99.55,36.03,35.81,25.50,17.18$; HSQC (cross-peaks) 1.27/17.37, 3.19/36.17, 3.68/35.99, 7.56/128.70, 7.58/131.58, 7.74/128.83, 7.82/127.68, 7.99/135.74, 8.25/129.69, 8.54, 125.78; LC-MS, m/z $=361[\mathrm{M}+1]$; Calculated for: $\mathrm{C}_{20} \mathrm{H}_{16} \mathrm{~N}_{4} \mathrm{O}_{3}$ : C, 66.66; H, 4.48; N, 15.55; Found: C, 66.68; H, 4.51; N, 15.58.

2-Methyl-3-(2-oxo-3-(p-tolyl)-2H-[1,2,4]triazino [2,3-c]quinazoline-6-yl)propanoic (2.3). Yield - 52.6\%. M.p. $-238-241^{\circ} \mathrm{C} ;{ }^{1} \mathrm{H}$ NMR (400 MHz, DMSO-d6) $\delta 12.11$ $(\mathrm{s}, 1 \mathrm{H}, \mathrm{COOH}), 8.60(\mathrm{~d}, J=7.5 \mathrm{~Hz}, 1 \mathrm{H}, \mathrm{H}-8), 8.23(\mathrm{~d}, J$ $=7.2 \mathrm{~Hz}, 2 \mathrm{H}, 3-\mathrm{Ph} \mathrm{H}-2,6), 7.97(\mathrm{t}, J=7.8 \mathrm{~Hz}, 1 \mathrm{H}, \mathrm{H}-9)$, $7.82(\mathrm{~d}, J=7.9 \mathrm{~Hz}, 1 \mathrm{H}, \mathrm{H}-8), 7.72(\mathrm{t}, J=7.8 \mathrm{~Hz}, 1 \mathrm{H}$, $\mathrm{H}-10$ ), 7.33 (d, $J=7.5 \mathrm{~Hz}, 2 \mathrm{H}, 3-\mathrm{Ph} \mathrm{H}-3,5), 3.73$ (dd, $J$

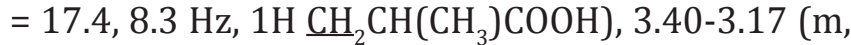
$\left.2 \mathrm{H}, \mathrm{CH}_{2} \underline{\mathrm{CH}}\left(\mathrm{CH}_{3}\right) \mathrm{COOH}\right), 2.45\left(\mathrm{~s}, 3 \mathrm{H}, \mathrm{CH}_{3}\right), 1.36(\mathrm{~d}, J=$ $\left.6.0 \mathrm{~Hz}, 3 \mathrm{H}, \mathrm{CH}_{2} \mathrm{CH}\left(\mathrm{CH}_{3}\right) \mathrm{COOH}\right) ; \mathrm{LC}-\mathrm{MS}, \mathrm{m} / \mathrm{z}=375[\mathrm{M}$ +1]; Calculated for: $\mathrm{C}_{21}^{-} \mathrm{H}_{18} \mathrm{~N}_{4} \mathrm{O}_{3}: \mathrm{C}, 67.37 ; \mathrm{H}, 4.85 ; \mathrm{N}$, 14.96; Found: C, 67.41; H, 4.89; N, 15.01.

3-(3-(4-Ethylphenyl)-2-oxo-2H-[1,2,4]triazino [2,3-c]quinazolin-6-yl)-2-methylpropanoic acid (2.4). Yield - 57.14\%. M.p. $-218-220^{\circ} \mathrm{C}$; ${ }^{1} \mathrm{H}$ NMR $(400 \mathrm{MHz}$, DMSO-d6) $\delta 12.11(\mathrm{~s}, 1 \mathrm{H}, \mathrm{COOH}), 8.60$ (d, $J=7.7 \mathrm{~Hz}$, $1 \mathrm{H}, \mathrm{H}-8), 8.24(\mathrm{~d}, J=6.9 \mathrm{~Hz}, 2 \mathrm{H}, 3-\mathrm{Ph} \mathrm{H}-2,6), 7.97(\mathrm{t}, J=$ $7.7 \mathrm{~Hz}, 1 \mathrm{H}, \mathrm{H}-9), 7.83$ (d, J = 7.7 Hz, 1H, H-8), 7.73 (t, $J$ $=7.6 \mathrm{~Hz}, 1 \mathrm{H}, \mathrm{H}-10), 7.36$ (d, $J=7.7 \mathrm{~Hz}, 2 \mathrm{H}, 3-\mathrm{Ph} \mathrm{H}-3,5)$, $3.73\left(\mathrm{dd}, J=17.6,8.3 \mathrm{~Hz}, 1 \mathrm{H}, \mathrm{CH}_{2} \mathrm{CH}\left(\mathrm{CH}_{3}\right) \mathrm{COOH}\right), 3.34-$ $3.18\left(\mathrm{~m}, 2 \mathrm{H}, \mathrm{CH}_{2} \mathrm{CH}\left(\mathrm{CH}_{3}\right) \mathrm{COOH}\right), 2.75(\mathrm{dd}, J=13.7,6.4 \mathrm{~Hz}$, $\left.2 \mathrm{H}, \mathrm{CH}_{2} \mathrm{CH}_{3}\right), 1.36\left(\mathrm{~d}, J=5.7 \mathrm{~Hz}, 3 \mathrm{H}, \mathrm{CH}_{2} \mathrm{CH}\left(\mathrm{CH}_{3}\right) \mathrm{COOH}\right)$, $1.31\left(\mathrm{t}, J=7.4 \mathrm{~Hz}, 3 \mathrm{H}, \mathrm{CH}_{2} \mathrm{CH}_{3}\right) ; \mathrm{LC}-\mathrm{MS}, \mathrm{m} / \mathrm{z}=389[\mathrm{M}$ +1]; Calculated for: $\mathrm{C}_{22} \mathrm{H}_{20} \mathrm{~N}_{4} \mathrm{O}_{3}$ : C, 68.03; $\mathrm{H}, 5.19$; $\mathrm{N}$, 14.42; Found: C, 68.07; H, 5.22; N, 14.45.

3-(3-(4-Isopropyl)-2-oxo-2H-[1,2,4]triazino [2,3-c]quinazolin-6-yl)-2-methylpropanoic acid (2.5). Yield - 45.0\%. M.p. $-179-183^{\circ} \mathrm{C} ;{ }^{1} \mathrm{H}$ NMR $(400 \mathrm{MHz}$, DMSO-d6) $\delta 12.32$ (s, 1H, COOH), 8.57 (d, $J=8.0 \mathrm{~Hz}$, $1 \mathrm{H}, \mathrm{H}-8$ ), 8.22 (d, $J=7.4 \mathrm{~Hz}, 2 \mathrm{H}, 3-\mathrm{Ph} \mathrm{H}-2,6), 8.01$ (t, $1 \mathrm{H}, J=8.0, \mathrm{H}-9), 7.84(\mathrm{~d}, J=7.8 \mathrm{~Hz}, 1 \mathrm{H}, \mathrm{H}, \mathrm{H}-8), 7.77$ (t, 
$J=7.4 \mathrm{~Hz}, 1 \mathrm{H}, \mathrm{H}-10), 7.45$ (d, $J=7.3 \mathrm{~Hz}, 1 \mathrm{H}, 3-\mathrm{Ph} \mathrm{H}-3$, 5), $3.69\left(\mathrm{dd}, J=16.0,6.8 \mathrm{~Hz}, 1 \mathrm{H},-\mathrm{CH}_{2} \mathrm{CH}\left(\mathrm{CH}_{3}\right) \mathrm{COOH}\right)$, 3.31-3.14 (m, $\left.2 \mathrm{H},-\mathrm{CH}_{2} \mathrm{CH}\left(\mathrm{CH}_{3}\right) \mathrm{COOH}\right), 3.00(\mathrm{dt}, J=12.9$, $\left.6.6 \mathrm{~Hz}, 1 \mathrm{H},-\mathrm{CH}\left(\mathrm{CH}_{3}\right)_{2}\right), 1.42-1.13\left(\mathrm{~m}, 9 \mathrm{H},-\mathrm{CH}_{2} \mathrm{CH}\left(\mathrm{CH}_{3}\right)\right.$ COOH, $\left.\left.-\mathrm{CH}\left(\mathrm{CH}_{3}\right)_{2}\right)\right)$. LC-MS, $\mathrm{m} / \mathrm{z}=403[\mathrm{M}+1]$; Calculated for: $\mathrm{C}_{23} \mathrm{H}_{22} \mathrm{~N}_{4} \mathrm{O}_{3}$ : C, 68.64; $\mathrm{H}, 5.51 ; \mathrm{N}, 13.92$; Found: C, 68.66; H, 5.55; N, 13.97 .

3-(3-(4-Ethoxypenyl)-2-oxo-2H-[1,2,4]triazino [2,3-c]quinazoline-6-yl)-2-methylpropanoic acid (2.6). Yield - 56.2\%. M.p. - 244-247 ${ }^{\circ}$; ${ }^{1} \mathrm{H}$ NMR $(400 \mathrm{MHz}$, DMSO-d6) $\delta 12.10(\mathrm{~s}, 1 \mathrm{H}, \mathrm{COOH}), 8.60(\mathrm{~d}, J=7.7 \mathrm{~Hz}$, $1 \mathrm{H}, \mathrm{H}-8), 8.37$ (d, $J=7.7 \mathrm{~Hz}, 2 \mathrm{H}, 3-\mathrm{Ph} \mathrm{H}-2,6), 7.96$ (t, $J=7.2 \mathrm{~Hz}, 1 \mathrm{H}, \mathrm{H}-9), 7.82$ (d, $J=7.7 \mathrm{~Hz}, 1 \mathrm{H}, \mathrm{H}-8), 7.72$ $(\mathrm{t}, J=7.4 \mathrm{~Hz}, 1 \mathrm{H}, \mathrm{H}-10), 7.02(\mathrm{~d}, J=7.8 \mathrm{~Hz}, 2 \mathrm{H}, 3-\mathrm{Ph}$ $\mathrm{H}-3,5), 4.14\left(\mathrm{~m}, 2 \mathrm{H},-\mathrm{OCH}_{2} \mathrm{CH}_{3}\right), 3.74(\mathrm{dd}, J=16.7$, $\left.7.5 \mathrm{~Hz}, 1 \mathrm{H}, \mathrm{CH}_{2} \mathrm{CH}\left(\mathrm{CH}_{3}\right) \mathrm{COOH}\right), 3.35-3.18(\mathrm{~m}, 2 \mathrm{H}$, $\left.\mathrm{CH}_{2} \mathrm{CH}\left(\mathrm{CH}_{3}\right) \mathrm{COOOH}\right), 1.45\left(\mathrm{t}, J=6.3 \mathrm{~Hz}, 3 \mathrm{H}, \mathrm{OCH}_{2} \mathrm{CH}_{3}\right)$, $1.36\left(\mathrm{~d}, J=5.7 \mathrm{~Hz}, 2 \mathrm{H}, \mathrm{CH}_{2} \mathrm{CH}\left(\mathrm{CH}_{3}\right) \mathrm{COOH}\right) ; \mathrm{LC}-\mathrm{MS}$, $\mathrm{m} / \mathrm{z}=405[\mathrm{M}+1]$; Calculated for: $\mathrm{C}_{22} \mathrm{H}_{20} \mathrm{~N}_{4} \mathrm{O}_{4}: \mathrm{C}, 65.34$; H, 4.98; N, 13.85; Found: C, 65.38; H, 4.99; N, 13.89 .

3-Methyl-1-(2-(6-methyl-5-oxo-2,5-dihydro-1, 2,4-triazin-3-yl)phenyl)pyrrolidine-2,5-dione (3.1). Yield - 12.1\%. M.p. - 249-251 ${ }^{\circ} \mathrm{C}$; ${ }^{1} \mathrm{H}$ NMR $(400 \mathrm{MHz}$, DMSO-d6) $\delta 13.90(\mathrm{~s}, 1 \mathrm{H}, \mathrm{NH}), 7.79(\mathrm{~d}, 1 \mathrm{H}, \mathrm{H}-3)$, 7.73 (t, 1H, H-5), 7.63 (t, 1H, H-4), 7.42 (d, 1H, H-6), 3.35-2.83 (m, $\left.2 \mathrm{H},-\mathrm{COCH}_{2} \mathrm{CH}\left(\mathrm{CH}_{3}\right) \mathrm{CO}-\right), 2.39(\mathrm{~m}, 1 \mathrm{H}$ $\left.-\mathrm{COCH}_{2} \mathrm{CH}\left(\mathrm{CH}_{3}\right) \mathrm{CO}-\right), 2.2 \frac{2}{4}\left(\mathrm{~s}, 1 \mathrm{H}, \mathrm{CH}_{3}\right), 1.32(\mathrm{~d}, 3 \mathrm{H}$, $\left.-\mathrm{COCH}_{2} \mathrm{CH}\left(\mathrm{CH}_{3}\right) \mathrm{CO}-\right) ; \mathrm{LC}-\mathrm{MS}, \mathrm{m} / \mathrm{z}=299$ [M +1]; Calculated for: $\mathrm{C}_{15}^{3} \mathrm{H}_{14} \mathrm{~N}_{4} \mathrm{O}_{3}$ : C, 60.40; $\mathrm{H}, 4.73 ; \mathrm{N}, 18.78$; Found: C, 60.43; H, 4.76; N, 18.80 .

The synthetic method of 3-(2-oxo-3-phenyl-2H[1,2,4]triazino[2,3-c]quinazoline-6-yl)-2-phenylpropanoic acid.

To the suspension of $0.003 \mathrm{M}(0.79 \mathrm{~g})$ of 3-(2-aminophenyl)-6-phenyl-1,2,4-triazin-5(2H)-one in $15 \mathrm{ml}$ of acetic acid add $0.003 \mathrm{M}(0.53 \mathrm{~g}) 2$-plsuccinic anhydride, reflux the mixture for 6 hours and cool. Evaporate the solvent under low pressure, then add $10 \mathrm{ml}$ of methanol. Filter the precipitate formed and crystallize from propanol-2.

3-(2-Oxo-3-phenyl-2H-[1,2,4]triazino[2,3-c]quinazolin-6-yl)-2-phenylpropanoic acid (4.1). Yield 56.3\%. M.p. - 186-188 ${ }^{\circ}$; ${ }^{1} \mathrm{H}$ NMR (400 MHz, DMSO-d6) $\delta 12.59(\mathrm{~s}, 1 \mathrm{H}, \mathrm{COOH}), 8.57(\mathrm{~d}, J=8.1 \mathrm{~Hz}, 1 \mathrm{H}, \mathrm{H}-11)$, 8.21 (d, $J=7.1 \mathrm{~Hz}, 2 \mathrm{H}, 3-\mathrm{Ph} \mathrm{H}-2,6), 8.03$ (t, $J=7.7 \mathrm{~Hz}$, $1 \mathrm{H}, \mathrm{H}-9), 7.83$ (d, $J=8.1 \mathrm{~Hz}, 1 \mathrm{H}, \mathrm{H}-8), 7.78(\mathrm{t}, J=7.6 \mathrm{~Hz}$, 1H, H-10), 7.71-7.05 (m, 8H, 3-Ph H-3,4,5, 6-Ph H-2, 3, $4,5,6), 4.43$ (dd, $\left.J=9.5,4.7 \mathrm{~Hz}, 1 \mathrm{H}, \mathrm{CH}_{2} \mathrm{CH}(\mathrm{Ph}) \mathrm{COOH}\right)$, 4.07 (dd, $J=17.6,9.4 \mathrm{~Hz}, 1 \mathrm{H}, \mathrm{CH}_{2} \mathrm{CH}(\mathrm{Ph}) \mathrm{COOH}$ ), 3.53 (dd, $J=17.6,4.7 \mathrm{~Hz}, 1 \mathrm{H}, \mathrm{CH}_{2} \mathrm{CH}(\mathrm{Ph}) \mathrm{COOH}$ ). LC-MS, $\mathrm{m} / \mathrm{z}=423[\mathrm{M}+1]$; Calculated for: $\mathrm{C}_{25} \mathrm{H}_{18} \mathrm{~N}_{4} \mathrm{O}_{3}: \mathrm{C}, 71.08$; H, 4.30; N, 13.26; Found: C, 71.10; H, 4.33; N, 13.28 .

1-(2-(5-Oxo-6-phenyl-2,5-dihydro-1,2,4-triazin3-yl)phenyl)-3-phenylpyrrolidine-2,5-dione (4.1). Yield - 21.4\%. M.p. $-223-224^{\circ} \mathrm{C}$; ${ }^{1} \mathrm{H}$ NMR $(400 \mathrm{MHz}$, DMSO-d6) $\delta \delta 13.88(\mathrm{~s}, 1 \mathrm{H}, \mathrm{NH}), 8.21(\mathrm{~d}, J=7.1 \mathrm{~Hz}$, 2H, 3-Ph H-2,6), 7.79 (d, 1H, H-3), 7.73 (t, 1H, H-5),
7.71-7.05 (m, 10H, H-4, H-6, 3-Ph H-3,4,5, 6-Ph H-2, 3, 4, 5, 6), 4.02 (dd, $J=17.6,9.4 \mathrm{~Hz}, 2 \mathrm{H}, \underline{\mathrm{CH}}_{2} \mathrm{CH}(\mathrm{Ph})$ ), 3.44 (dd, $J=17.6,4.7 \mathrm{~Hz}, 1 \mathrm{H}, \mathrm{CH}_{2} \mathrm{CH}(\mathrm{Ph})$ ). LC-MS, m/z $=423[\mathrm{M}+1]$; Calculated for: $\mathrm{C}_{25} \mathrm{H}_{18} \mathrm{~N}_{4} \mathrm{O}_{3}: \mathrm{C}, 71.08$; H, 4.30; N, 13.26; Found: C, 71.13; H, 4.35; N, 13.31 .

The general method for synthesis of substituted 1,2,2-trimethyl-3-(3-R-2-oxo-2H-[1,2,4]triazino [2,3-c]quinazolin-6-yl)cyclopentane-1-carboxylic acids. To the suspension of $0.003 \mathrm{M}(0.79 \mathrm{~g})$ of the corresponding 3-(2-aminophenyl)-6-R-1,2,4-triazin$5(2 \mathrm{H})$-one in $15 \mathrm{ml}$ of acetic acid add $0.003 \mathrm{M}(0.91 \mathrm{~g})$ of camphoric anhydride, heat the mixture at $80^{\circ} \mathrm{C}$ for $30 \mathrm{~min}$, then reflux for 6 hours and cool. Evaporate the solvent under low pressure, then add $20 \mathrm{ml}$ of methanol. Filter the precipitate formed and dry.

1,2,2-Trimethyl-3-(3-methyl-2-oxo-2H-[1,2,4]triazino[2,3-c]quinazolin-6-yl)cyclopentane-1-carboxylic acid (6.1). Yield $-31.2 \%$. M.p. $=285-296^{\circ} \mathrm{C}$; ${ }^{1} \mathrm{H}$ NMR (400 MHz, DMSO-d6) $\delta 11.91$ (s, 1H, COOH), $8.55(\mathrm{~d}, \mathrm{~J}=8.0 \mathrm{~Hz}, 1 \mathrm{H}$, triazinoquinazoline $\mathrm{H}-11)$, $7.92(\mathrm{t}, \mathrm{J}=7.3 \mathrm{~Hz}, 1 \mathrm{H}$, triazinoquinazoline $\mathrm{H}-9), 7.79$ (d, J = $8.1 \mathrm{~Hz}, 1 \mathrm{H}$, triazinoquinazoline $\mathrm{H}-8), 7.67(\mathrm{t}$, $\mathrm{J}=7.5 \mathrm{~Hz}, 1 \mathrm{H}$, triazinoquinazoline $\mathrm{H}-10), 4.60(\mathrm{t}, \mathrm{J}=$ $8.9 \mathrm{~Hz}, 1 \mathrm{H}$, cyclopentane $\mathrm{H}-3), 2.74-2.53(\mathrm{~m}, 2 \mathrm{H}$, cyclopentane $\mathrm{H}-4,5), 2.40$ (s, 3H, triazinoquinazoline-3 $\mathrm{CH}_{3}$ ), 2.12-1.92 (m, 1H, cyclopentane H-5), 1.54 (t, J $=9.4 \mathrm{~Hz}, 1 \mathrm{H}$, cyclopentane $\mathrm{H}-4), 1.34(\mathrm{~s}, 3 \mathrm{H}$, cyclopentane- $\left.1 \mathrm{CH}_{3}\right), 1.16\left(\mathrm{~s}, 3 \mathrm{H}\right.$, cyclopentane- $\left.2 \mathrm{CH}_{3}\right), 0.79$ (s, 3H, cyclopentane- $\left.2 \mathrm{CH}_{3}\right) ;{ }^{13} \mathrm{C}$ NMR $(101 \mathrm{MHz}$, DMSO) $\delta 176.41,159.64,154.20,153.53,151.77,142.86,134.68$, $127.90,127.20,125.29,119.04,56.10,48.21,45.55$, $32.31,25.74,22.90,21.85,21.33,17.58$; EI-MS m/z (\% rel.) 366 (5.7), 325 (16.8), 321 (29.0), 310 (6.9), 298 (5.0), 297 (30.4), 296 (7.2), 281 (7.0), 280 (39.7), 279 (7.7), 265 (6.8), 264 (23.4), 240 (8.2), 239 (61.3), 238 (16.4), 236 (12.3), 227 (6.4), 226 (8.1), 212 (9.5), 211 (24.1), 210 (62.0), 209 (17.1), 199 (14.3), 198 (100), 197 (15.5), 196 (23.4), 185 (14.2), 183 (13.4), 181 (5.4), 172 (11.3), 171 (28.4), 170 (8.8), 169 (8.7), 168 (6.3), 167 (6.8), 155 (10.4), 145 (7.0), 144 (7.4), 143 (36.7), 142 (11.2), $140(7.8), 139$ (14.3), 129 (13.2), $118(16.5)$, 117 (8.9), 116 (10.7), 115 (9.3), 112 (7.1), 111 (18.2), 110 (8.5), 109 (21.9), 107 (7.0), 105 (5.0), 104 (5.4), 98 (6.3), 89 (5.5), 87 (6.5), 86 (5.2), 85 (19.3), 83 (13.1), 81 (27.4), 80 (5.9), 79 (15.5), 77 (21.9), 76 (14.0), 75 (11.9), 74 (5.0), 73 (19.8), 69 (15.9), 68 (5.8), 67 (10.5), 57 (23.3), 56 (24.1), 55 (64.5), 54 (10.1), 53 (10.9), 50 (8.0), 49 (80.3), 48 (10.8), 47 (28.2), 45 (28.3), 44 (39.1), 43 (89.9), 42 (21.2), 41 (5.3); LC-MS $\mathrm{m} / \mathrm{z}=369(\mathrm{M}+1)$; Calculated for $\mathrm{C}_{20} \mathrm{H}_{22} \mathrm{~N}_{4} \mathrm{O}_{3} \mathrm{C}, 65.56$; H, 6.05; N, 15.29; Found C, 65.58; H, 6.07; N, 15.31; $0,13.12$.

1,2,2-Trimethyl-3-(3-phenyl-2-oxo-2H-[1,2,4]triazino[2,3-c]quinazolin-6-yl)cyclopentane-1-carboxylic acid (6.2). Yield - 18.7\%. M.p. - 266-269 ${ }^{\circ} \mathrm{C}$; ${ }^{1} \mathrm{H}$ NMR (400 MHz, DMSO-d6) $\delta 11.94(\mathrm{~s}, 1 \mathrm{H}, \mathrm{COOH})$, $8.63(\mathrm{~d}, \mathrm{~J}=7.8 \mathrm{~Hz}, 1 \mathrm{H}$, triazinoquinazoline $\mathrm{H}-11), 8.32$ 
(d, J = 6.9 Hz, 1H, triazinoquinazoline-3 $\mathrm{Ph} \mathrm{H}-2,6$ ), $7.97(\mathrm{t}, \mathrm{J}=7.3 \mathrm{~Hz}, 1 \mathrm{H}$ triazinoquinazoline $\mathrm{H}-9), 7.85$ $(\mathrm{d}, \mathrm{J}=8.0 \mathrm{~Hz}, 1 \mathrm{H}$, triazinoquinazoline $\mathrm{H}-8), 7.73(\mathrm{t}$, $\mathrm{J}=7.4 \mathrm{~Hz}, 1 \mathrm{H}$, triazinoquinazoline $\mathrm{H}-10$ ), 7.67-7.40 (m, 3H, triazinoquinazoline-3 $\mathrm{Ph} \mathrm{H}-3,4,5), 4.76$ (t, J $=9.0 \mathrm{~Hz}, 1 \mathrm{H}$, cyclopentane $\mathrm{H}-3), 2.82-2.57(\mathrm{~m}, 1 \mathrm{H}$, cyclopentane $\mathrm{H}-4,5), 2.19-1.96(\mathrm{~m}, 1 \mathrm{H}, \mathrm{H}-5), 1.69$ $1.49(\mathrm{~m}, 1 \mathrm{H}$, cyclopentane, H-4), $1.40(\mathrm{~s}, 1 \mathrm{H}$, cyclopentane- $\left.1 \mathrm{CH}_{3}\right), 1.17\left(\mathrm{~s}, 1 \mathrm{H}\right.$, cyclopentane- $\left.2 \mathrm{CH}_{3}\right), 0.88$ (s, $1 \mathrm{H}$, cyclopentane-2 $\mathrm{CH}_{3}$ ). LC-MS m/z = $431(\mathrm{M}+1)$; Calculated for $\mathrm{C}_{25} \mathrm{H}_{24} \mathrm{~N}_{4} \mathrm{O}_{3}$ C, 70.08; $\mathrm{H}, 5.65 ; \mathrm{N}, 13.08$; Found: C, 70.11; H, 5.68; N, 13.11 .

1,2,2-Trimethyl-3-(3-(4-isopropylphenyl)-2-oxo2H-[1,2,4]triazino[2,3-c]quinazolin-6-yl)cyclopentane-1-carboxylic acid (6.3). Yield - 34.81\%. M.p. 270-272 ${ }^{\circ} \mathrm{C}$; ${ }^{1} \mathrm{H}$ NMR (400 MHz, DMSO-d6) $\delta 11.97$ (s, $1 \mathrm{H}, \mathrm{COOH}), 8.63(\mathrm{~d}, \mathrm{~J}=7.9 \mathrm{~Hz}, 1 \mathrm{H}$, triazinoquinazoline $\mathrm{H}-11), 8.27$ (d, J = $8.1 \mathrm{~Hz}$, triazinoquinazoline-3 $\mathrm{Ph} \mathrm{H}-2,6), 7.97(\mathrm{t}, \mathrm{J}=7.5 \mathrm{~Hz}, 1 \mathrm{H}$, triazinoquinazoline $\mathrm{H}-9), 7.85(\mathrm{~d}, \mathrm{~J}=8.1 \mathrm{~Hz}, 1 \mathrm{H}$, triazinoquinazoline $\mathrm{H}-8), 7.73(\mathrm{t}, \mathrm{J}=7.4 \mathrm{~Hz}, 1 \mathrm{H}$, triazinoquinazoline $\mathrm{H}-10$ ), 7.39 (d, J = 8.1 Hz, 1H, triazinoquinazoline-3 $\mathrm{Ph} \mathrm{H}-3,5), 4.77$ (t, J = 9.0 Hz, 1H, cyclopentane $\mathrm{H}-3$ ), $3.02\left(\mathrm{t}, \mathrm{J}=10.2 \mathrm{~Hz}, 1 \mathrm{H}, \underline{\mathrm{CH}}\left(\mathrm{CH}_{3}\right)_{2}, 2.80-2.54(\mathrm{~m}, 1 \mathrm{H}\right.$, cyclopentane $\mathrm{H}-4,5), 2.24-1.97$ (m, $1 \mathrm{H}$, cyclopentane-1 $\left.\mathrm{CH}_{3}\right), 1.66-1.53(\mathrm{~m}, 1 \mathrm{H}$, cyclopentane $\mathrm{H}-4), 1.42$ (s, $1 \mathrm{H}$, cyclopentane-1 $\left.\mathrm{CH}_{3}\right), 1.33(\mathrm{~d}, \mathrm{~J}=6.8 \mathrm{~Hz}, 6 \mathrm{H}$, $\left.\mathrm{CH}\left(\mathrm{CH}_{3}\right)_{2}\right), 1.19$ (s, $1 \mathrm{H}$, cyclopentane-2 $\left.\mathrm{CH}_{3}\right), 0.88$ (s, $1 \mathrm{H}$, cyclopentane-2 $\left.\mathrm{CH}_{3}\right)$; LC-MS m/z = $471(\mathrm{M}+1)$;
Calculated for $\mathrm{C}_{28} \mathrm{H}_{30} \mathrm{~N}_{4} \mathrm{O}_{3} \mathrm{C}, 71.47 ; \mathrm{H}, 6.43 ; \mathrm{N}, 11.91$; Found: C, C, 71.49; H, 6.45; N, 11.94

\section{$\mathrm{X}$-ray Experimental Part}

The colourless crystals of $\mathbf{6 . 1}\left(\mathrm{C}_{20} \mathrm{H}_{20} \mathrm{~N}_{4} \mathrm{O}_{3}\right)$ are monoclinic. At $193 \mathrm{~K} \mathrm{a}=10.332(1), \mathrm{b}=16.562(2), \mathrm{c}=$ 12.756(1) $\AA, \beta=113.245(5)^{\circ}, V=2005.5(4) \AA^{3}, M_{r}=$ $364.40, \mathrm{Z}=4$, space group $\mathrm{P} 2{ }_{1} / \mathrm{n}, \mathrm{d}_{\text {calc }}=1.207 \mathrm{~g} / \mathrm{cm}^{3}$, $\mu(\mathrm{MoK} \alpha)=0.083 \mathrm{~mm}^{-1}, \mathrm{~F}(000)=768$. Intensities of 24236 reflections (3501 independent, $R_{\text {int }}=0.053$ ) were measured on a "Bruker-Apex2" diffractometer (graphite monochromated MoK $\alpha$ radiation, CCD detector, $\omega$-scaning, $2 \Theta_{\max }=50^{\circ}$ ).

The structure was solved by the direct method using a SHELXTL package [13]. Positions of the hydrogen atoms were located from electron density difference maps and refined by the "riding" model with $\mathrm{U}_{\text {iso }}=\mathrm{nU}_{\mathrm{eq}}(\mathrm{n}=1.5$ for methyl and hydroxyl groups and $n=1.2$ for other hydrogen atoms) of the carrier atom. Full-matrix least-squares refinement against $\mathrm{F}^{2}$ in anisotropic approximation for non-hydrogen atoms using 3438 reflections was converged to $\mathrm{wR}_{2}$ $=0.199\left(R_{1}=0.067\right.$ for 2223 reflections with $F>4 \sigma(F)$, $\mathrm{S}=1.018$ ). The final atomic coordinates, and crystallographic data for molecule 6.1 were deposited from the Cambridge Crystallographic Data Centre, 12 Union Road, CB2 1EZ, UK (fax: +44-1223-336033; e-mail: deposit@ccdc.cam.ac.uk).They are available on request quoting the deposition numbers CCDC 1027014).

\section{References}

1. Sergeieva T. Yu., Voskoboynik O. Yu., Okovytyy S. I., Kovalenko S. I., Shishkina S. V., Shishkin O. V., Leszczynski J. J. Phys. Chem. A., 2014, 118, pp.18951905. doi: 10.1021/jp4052616.

2. Kovalenko S. I., Nosulenko I. S., Voskoboynik A. Yu., Berest G. G., Antipenko L. M., Antipenko A. N., Katsev A. M. Med. Chem. Res., 2013, 22(6), pp.26102632. doi: 10.1007/s00044-012-0257-X.

3. Kovalenko S. I., Nosulenko I. S., Voskoboynik A. Yu., Berest G. G., Antipenko L. M., Antipenko A. N., Katsev A. M. Sci. Pharm., 2012 , 80, pp.837-865. 10.3797/scipharm.1208-07.

4. Berest G. G., Voskoboynik O. Yu., Kovalenko S. I., Nosulenko I. S., Antipenko L. M., Antipenko O. M., Shvets V. M., Katsev A. M. Sci. Pharm., 2012, 80 (1), pp.37-65. doi:10.3797/scipharm.1111-15.

5. Berest G. G., Voskoboynik A. Yu., Kovalenko S. I., Antipenko A. M., Nosulenko I. S., Katsev A. M., Shandrovskaya A. S. Eur. J. Med. Chem., 2011, 46 (12), pp.6066-6074. doi: 10.1016/j.ejmech.2011.10.022.

6. Voskoboynik A. Yu., Scorina D. Yu., Sergeieva T. Yu., Kovalenko S. I., Okovytyy S. I., Omelchenko I. V., Shishkin O. V. J. Het. Chem. (in press) doi: 10.1002/ jhet.2120.

7. UA Utility Model Patent №U201214626 Salts of (3-R-8-R1-9-R2-10-R3-11-R4-2-oxo-2H-[1,2,4]triazino[2,3-c]quinazolin-6-yl) alkylcarboxylic acids improving physical endurance of body Stepaniuk H. I., Pochelova O. V., Chornoivan N. H., Voskoboinik O. Y., Skoryna D. Y., Kovalenko S. I. Published 20.12.2012.

8. UA Utility Model Patent №U201306088 Use of sodium salt of 4-(2-oxo-3-methyl-2H-[1,2,4]triazino[2,3-c]-quinazolin-6-yl) butanoic acid as cerebroprotective agents Semenenko N. O., Stepaniuk H. I., Semenenko A. I., Kovalenko S. I., Voskoboinik O. Yu., Skoryna D. Yu. Published 17.05.2013.

9. UA Utility Model Patent №U 2001064232 Antidiabetic agent "Diakamf", which reveals the hypoglycemic, antidiabetogenic and antioxidant action Merzlikin S. I., Chernykh V. P., Hladkykh O. I., Chueshov V. I., Pashnev P. D. Published 15.04.2002.

10. Karpenko O. V., Kovalenko S. I., Chekotylo O. O., Shishkina S. V. Heterocycles, 2007, 71 (3), pp.619-626. doi: 10.3987/COM-06-10971.

11. Zefirov Yu. V. Crystallography, 1997, 42 (5), pp.936-958.

12. Burgi H.-B., Dunitz J. D. Structure correlation. Vol. 2. VCH. Weinheim. 1994, pp.741-784.

13. Sheldrick G. M. Acta Crystallogr., Sect. A, 2008, A64, pp.112-122.

Надійшла до редакції 01.10.2014 p. 